\title{
Effects of prolactin on estrogen, cAMP and oxytocin secretion by porcine granulosa cells in vitro
}

\author{
AV Sirotkin, J Nitray \\ Research Institute of Animal Production, 94992 Nitra, Slovakia
}

(Received 25 November 1992; accepted 3 February1993)

\begin{abstract}
Summary - Granulosa cells were isolated from ovaries (without pre-ovulatory follicles or corpora lutea) of cycling gilts slaughtered at 8 months of age. They were cultured in the presence or absence of exogenous porcine prolactin $(1,10,1000,10000$, or $100000 \mathrm{pmol} / \mathrm{ml}$ medium). The secretion of estrogen, CAMP and oxytocin into the incubation medium was analysed by radioimmunoassay. It was found that prolactin $(10,1000,10000$ and $100000 \mathrm{pmol} / \mathrm{ml})$ inhibited estrogen secretion $(p<0.001)$ and stimulated cAMP output $(p<0.001, p<0.001$, not significant, and $p<0.01$, respectively). Small doses of prolactin ( 1 and $10 \mathrm{pmol} / \mathrm{ml}$ ) decreased $(p<0.001, p<$ $0.05)$, whilst high doses $(1000,10000$ and $100000 \mathrm{pmol} / \mathrm{ml})$ increased $(p<0.001)$ oxytocin secretion by granulosa cell culture. The data suggest a direct action of prolactin on porcine ovarian cyclic nucleotides, steroid and nonapeptide hormone release.
\end{abstract}

prolactin / estradiol / cAMP / oxytocin / ovary

Résumé - Effets de la prolactine sur la sécrétion d'œstrogène, d'AMPc et d'ocytocine par les cellules de la granulosa porcine in vitro. Les cellules de la granulosa ont été isolées d'ovaires (sans follicules préovulatoires, ni corps jaunes) de truies cycliques abattues à l'âge de 8 mois. Elles ont été cultivées en présence ou en absence de prolactine (PRL) porcine exogène (1, $10,1000,10000$ ou $100000 \mathrm{pmol} / \mathrm{ml}$ de milieu). La sécrétion d'œstrogène, d'AMPc et d'ocytocine dans le milieu d'incubation a été analysée par RIA. La PRL $(10,1000,10000$ et $100000 \mathrm{pmol} / \mathrm{m} /)$ inhibe la sécrétion d'cestrogène $(p<0,001)$ et stimule la production d'AMPC $(p<0,001 ; p<0,001$; non significatif et $p<0,01$ respectivement). Des petites doses de PRL (1 et $10 \mathrm{pmol} / \mathrm{ml})$ décroissent et des doses supérieures (1 000, 10000 et 100000 pmol/ml) augmentent $(\mathrm{p}<0,001)$ la sécrétion d'ocytocine par les cellules de la granulosa en culture. Ces résultats suggèrent une action directe de prolactine sur la sécrétion de nucléotides cycliques, de stéroïdes et d'ocytocine par l'ovaire porcin.

prolactine / œstradiol / AMPc / ocytocine / ovaire 


\section{INTRODUCTION}

There is data to suggest that prolactin (PRL) plays an important role in the regulation of reproductive cyclicity, lactational infertility and hyperprolactinemia-associated disfunctions of the gonads. In particular, PRL receptors have been demonstrated in granulosa and luteal cells in the pig (Dusza and Tilton, 1990) and in ovarian follicles in the hamster (Roy et al, 1987) but not in bovine ovarian follicles (Bevers et al, 1988). It was demonstrated that PRL can directly inhibit the function of premature ovarian follicles, stimulate luteinization of ovarian cells and development of the corpus luteum (see reviews by McNeilly et al, 1982; Murphy and Rajkumar, 1985; Tsafriri, 1988; Dusza and Tilton, 1990). However, information on the direct action of PRL is limited almost entirely to an influence on ovarian steroidogenesis and some of the data is contradictory. In particular, an artifical increase in blood PRL concentration failed to change steroid levels in bovine (Bevers et al, 1988), ovine and porcine (Dusza, 1989; Dusza and Tilton, 1990) plasma. On the other hand, PRL inhibited steroid production by rat ovaries in vivo (Kalison et al, 1985, Adashi and Resnik, 1987), by perfused human ovaries (Demura et al, 1982), by human (Sato et al, 1985), pig (Rajkumar et al, 1988) and rat (Adashi and Resnik, 1987; Gitay-Goren et al, $1989 a, b)$ granulosa cells, and by rat thecainterstitial cells (Magoffin and Erikson, 1982; McNeilly, 1984). Aromatase activity in isolated hen ovarian follicles (Zadworny et al, 1989) and rat granulosa cells (Dorrington and Gore-Langton, 1982; Wang and Chan, 1982; Gitay-Goren et al, 1989 a,b; Krasnow et al, 1990) was also inhibited. In other reports, PRL stimulated progesterone production by rat (Wang and Chan, 1982) and porcine (Einspanier et al, 1986) granulosa cell cultures.

PRL stimulated $\mathrm{LH}$ receptor formation (Murphy and Rajkumar, 1985; Adashi and
Resnik, 1987), lipoprotein uptake (Murphy and Rajkumar, 1985; Rajkumar et al, 1988) and progesterone (Grinwich et al, 1983; Murphy and Rajkumar et al, 1988) and progesterone (Grinwich et al, 1983; Murphy and Rajkumar, 1985) but not androgen (Gregoraszczuk, 1985) release from porcine luteal cells. PRL also activated lipoprotein utilization and progesterone production by porcine granulosa cells luteinized in culture (Chedreese et al, 1988). In rat luteal cells, PRL stimulated progesterone, testosterone and estradiol release (Kalison et al, 1985; Menon et al, 1985; Murphy and Rajkumar, 1985, Gitay-Goren et al, 1989a). Enhanced progesterone output was observed after PRL treatment in human corpus luteum slices in culture (Hunter, 1989). In other in vitro experiments PRL either had no effect on porcine luteal cell progesterone production (Gregoraszczuk, 1985) or it was inhibitory (Grazul, 1985; Einspanier et al, 1986). Thus, although most of the available data suggest that PRL inhibits steroidogenesis in follicular tissue and stimulates it in luteal tissue there is no concensus regarding its overall effect on the ovary.

In addition to steroid hormones, the ovary produces other biologically active substances including the nonapetide hormone oxytocin and the cyclic nucleotide CAMP, which are also potent regulators of ovarian function (Guraya, 1985; Hansel and Dowd, 1986; Richards and Hedin, 1988; Tsafriri, 1988; Wathes, 1989). There is little information concerning PRL's influence on the non-steroidal ovarian substances. GitayGoren et al $(1989 a, b)$ reported that PRL inhibited CAMP release from rat granulosa cells in culture, in contrast to its effect on mammary tissue (Rillema et al, 1988). The phosphodiesterase inhibitor 3-isobutyl-1methylxanthine abolished the PRL effect indicating that PRL may activate phosphodiesterase within ovarian cells. In rat luteal cell culture the same authors observed PRLinduced stimulation of CAMP accumulation. 
The effects of PRL on the ovarian cells of other species have not been investigated.

The aim of the present studies was to examine the role of PRL in the regulation of estrogen, cAMP and oxytocin secretion by porcine granulosa cells in culture.

\section{MATERIALS AND METHODS}

\section{Preparation and culture of granulosa cells}

Ovaries in the late and middle follicular phase of the estrous cycle were obtained from Slovakian white gilts, 8 months of age without visible reproductive abnormalities, at a local slaughterhouse. Ovaries with preovulatory or hemorrhagic follicles were excluded. One hour after killing, the contents of 2-5 mm diameter follicles were aseptically aspirated with a syringe. Granulosa cells were separated from follicular fluid by 5 min centrifugation at $200 \mathrm{~g}$ and resuspended in sterile TCM 199 (Sigma, St Louis, USA) supplemented with $5 \%$ bovine fetal serum (Institute of Veterinary Medicine, Brno, Czechia). The sequence of centrifugation and resuspension was carried out 3 times. After the final centrifugation, granulosa cells were resuspended in incubation medium TCM 199 supplemented with $10 \%$ bovine fetal serum, $10 \mathrm{mlU} / \mathrm{ml}$ insulin (Lečiva, Prague, Czechia), $200 \mu \mathrm{g} / \mathrm{ml}$ pyruvate $\mathrm{Na}$ (Serva, Heidelberg, FGR), $600 \mu \mathrm{g} / \mathrm{ml}$ lactate $\mathrm{Ca}$ (Serva, Heidelberg, FRG) $50 \mathrm{mg} / \mathrm{ml}$ gentamicin (Pharmachim, Sophia, Bulgaria). A $2 \mathrm{ml}$ portion of suspension (concentration $10^{6}$ celis $/ \mathrm{ml}$ ) was transferred to cell-cult plate wells (Sterilin Ltd, Feltham, England) and incubated at $38.5^{\circ} \mathrm{C}$ in $5 \% \mathrm{CO}_{2}$ in humidified air. Cell viability (determined by trypsan blue stain) was $75-85 \%$. After $2 \mathrm{~d}$ culture, when practically all the cells were attached to the bottom of the wells, the medium was replaced. PRL was added to the medium of experimental groups to final concentrations of $1,10,100,1000,10000$, or 100000 $\mathrm{pmol} / \mathrm{ml}$. USDA pPRL B-1, a pure PRL preparation of analytical grade for radioimmunoassay (RIA) standards, was kindly given by Dr AF Parlow (Harbor-UCLA Medical Center, Torrance, USA) to Dr GV Marinchenko (Research Institute of Animal Breeding and Genetics, St Petersburg, Pushkin, Russia) and was used in all experiments. The preparation was dissolved immediately before the addition to the medium. After $2 \mathrm{~d}$ culture, the medium was gently aspirated with a syringe and frozen at $-40^{\circ} \mathrm{C}$ to await hormone analysis. Counting the cells at this point revealed an approximately 2 -fold increase in cell number. Viability varied between 55 and $65 \%$. No statistically significant influence of PRL treatment on cell number or viability was observed. In an initial experiment, medium samples were collected after $2 \mathrm{~d}$ culture in the absence of cells so as to determine any background hormone concentration.

\section{Radioimmunoassays}

Estrogen, CAMP and oxytocin concentrations were determined in duplicate by RIA without extraction.

Estrogen concentrations were measured with commercial kits for estradiol measurement of the Institute for Radioecology and Application of Nuclear Techniques (URVJT, Kosice, CFSR) following the manufacturers' instructions. The sensitivity of determination was $0.025 \mathrm{pmol} / \mathrm{ml}$. The cross-reaction of the antiserum was $25 \%$ with estron, $1.84 \%$ with estriol, and less than $0.001 \%$ with $20-\mathrm{OH}$ progesterone, androstenedione, testosterone, cortisol and cortisone. The inter- and intraassay coefficients of variation did not exceed 3 and $4 \%$, respectively.

cAMP concentrations were determined using RIA kits from the Institute for Research, Production and Application of Radioisotopes (UVVVR, Prague, CSFR). The sensitivity was $0.05 \mathrm{fmol} / \mathrm{ml}$. The cross-reaction of the antiserum with CGMP was less than $0.01 \%$ and with AMP, ADP and ATP less than $0.003 \%$. The interand intraassay coefficients of variation did not exceed 7 and $9 \%$, respectively.

Oxytocin levels were measured by kits from UVVR. The sensitivity was $1.2 \mathrm{fmol} / \mathrm{ml}$. The antiserum cross-reacted at less than $0.005 \%$ with arginine-vasopressin, $0.04 \%$ with lysine-vasopressin, $17 \%$ with arginine-vasotocin and $22.6 \%$ with desamino-oxytocin. Interassay coefficient of variation varied between 11 and $12 \%$, and the intraassay coefficient of variation did not exceed $9 \%$.

\section{Statistics}

The data presented are the values obtained from 3 separate experiments, each using a pool of granulosa cells isolated from 30-40 ovaries. Each 
experimental group was represented by 4 culture wells. Since the serum-supplemented medium contained small amounts of estradiol, cAMP and oxytocin (table I), the pre-culture medium for each experimental group was used as a background control. Rates of estrogen, CAMP and oxytocin secretion were calculated to $10^{6}$ viable cells/d. Significant differences between the groups were evaluated by ANOVA, followed by Duncan's test for individual significant differences.

\section{RESULTS}

Initial experiments (table I) showed that significant quantities of estrogen, cAMP and oxytocin áccumulate in the medium during the culture of granulosa cells. After $2 d$, the concentrations of these substances in the medium exceeded initial levels by 2.4-2.6 times $(p<0.01, p<0.001$ and $p<0.001$, respectively). Addition of $P R L$ influenced the secretion of substances as follows. PRL doses of $10 \mathrm{nmol} / \mathrm{ml}$ and above significantly $(p<0.001)$ reduced estrogen release (fig 1$)$. PRL doses of 10 and $1000 \mathrm{pmol} / \mathrm{ml}$ significantly $(p<0.001)$ increased cyclic nucleotide CAMP accumulation (fig 2). Higher PRL doses produced a lower level of stimulation and the effect at $10000 \mathrm{pmol} / \mathrm{ml}$ was not significant. Low PRL doses (1 or $10 \mathrm{pmol} / \mathrm{ml}$ ) decreased oxytocin release $(p<0.001$ and $p<0.05$ respectively) whilst doses of 1000 $\mathrm{pmol} / \mathrm{ml}$ and above were highly stimulatory $(p<0.01)$ (fig 3).

Table I. Estrogen, cAMP and oxytocin concentrations in porcine granulosa cell incubation medium before and after $2 \mathrm{~d}$ of culture.

\begin{tabular}{lrrr}
\hline Substance analyzed & & \multicolumn{2}{c}{ Concentration } \\
& Before culture & After 2 d culture & Differences \\
\hline Estrogen $(\mathrm{pmol} / \mathrm{ml})$ & $0.86 \pm 0.28$ & $2.22 \pm 0.48$ & $p<0.001$ \\
CAMP $(\mathrm{fmol} / \mathrm{ml})$ & $0.34 \pm 0.04$ & $0.80 \pm 0.04$ & $p<0.001$ \\
Oxytocin $(\mathrm{fmol} / \mathrm{ml})$ & $19.68 \pm 0.62$ & $48.50 \pm 11.42$ & $p<0.001$ \\
\hline
\end{tabular}

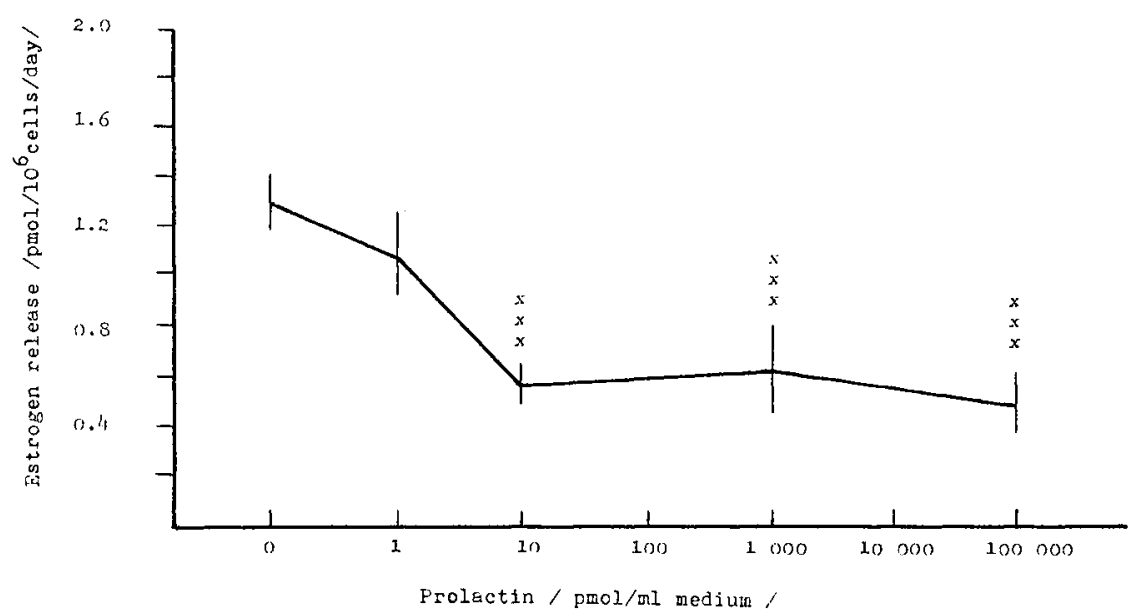

Fig 1. Effect of prolactin on estradiol-17ß secretion by porcine granulosa cells in vitro. Values are means \pm SEM. xxx: highly significant difference $(p<0.001)$ compared with control (without prolactin addition). 


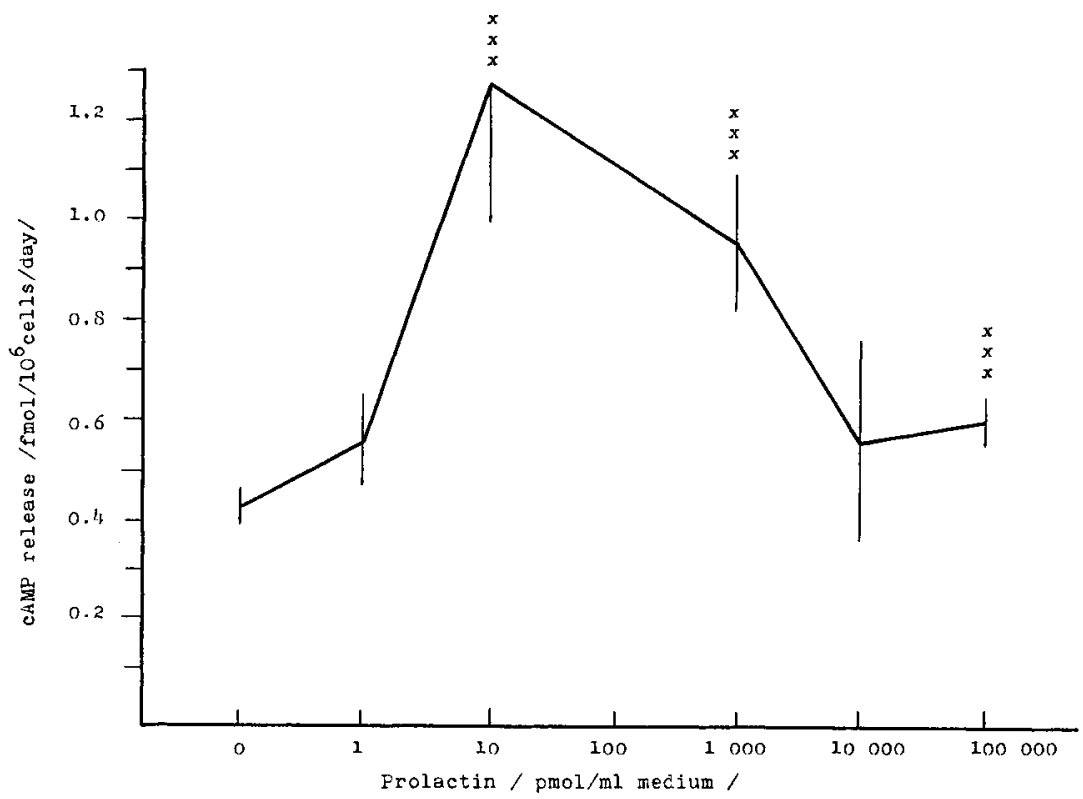

Fig 2. Effect of prolactin on cAMP release by porcine granulosa cells in vitro. Values are means \pm SEM. $\mathbf{x x}: p<0.01 ; \mathrm{xxx}: p<0.001$ compared with control (without prolactin addition).

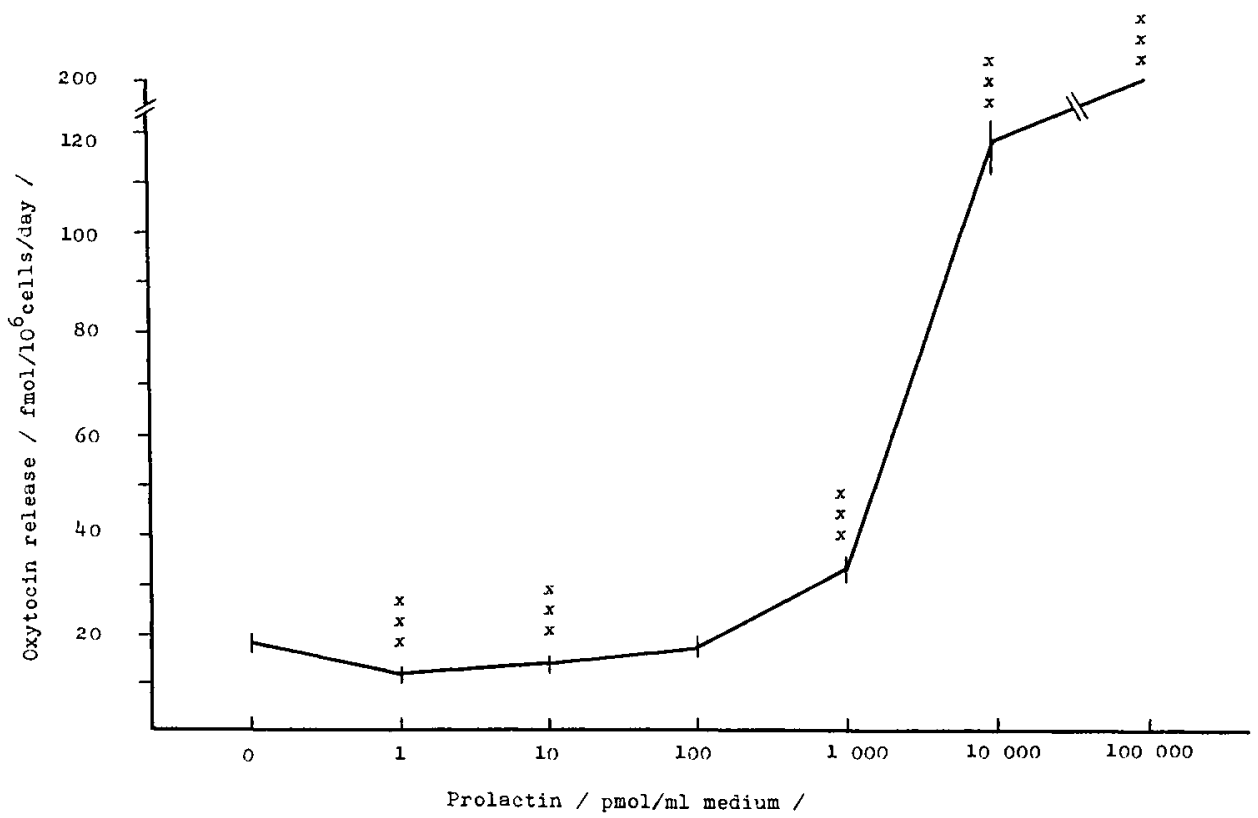

Fig 3. Effect of prolactin on oxytocin release by porcine granulosa cells in vitro. Values are means $\pm S E M$. $\mathrm{x}: p<0.05 ; \mathrm{xxx}: p<0.001$ compared with control (without prolactin addition). 


\section{DISCUSSION}

The results presented in table I are consistent with available data (Guraya, 1985; Wathes, 1989) concerning the ability of ovarian cells to release estradiol, CAMP and oxytocin in vitro. The significant inhibition of porcine granulosa estrogen output under the influence of PRL (fig 2) is in agreement with other reports on the suppressive effect of PRL on estradiol release (Dorrington and Gore-Langton, 1982; Wang and Chan, 1982; Gitay-Goren et al, 1989ab; Krasnow et al, 1990), particularly in hen (Zadworny et al, 1989) and human (Demura et al, 1982) ovarian follicular cells. It has been shown (Ledwitz-Rigby, 1987; Einspanier et al, 1991) that, as in other mammals (Guraya, 1985), the luteinization of porcine follicles in vivo and in vitro is associated with a decrease in estradiol release and with the subsequent stimulation of progesterone output. Figure 1 may suggest that PRL stimulated the luteinization of our granulosa cells in culture. Together with the information in the Introduction about PRL-induced inhibition of the production of other steroids by ovarian follicular cells, our results may support the hypothesis (McNeilly et al, 1982; Murphy and Rajkumar, 1985; Dusza and Tilton, 1990) that during corpus luteum development and lactation a high blood PRL level can inhibit follicular development, steroidogenesis and ovulation and maintain corpus luteum function.

These effects may be mediated by cAMP-dependent intracellular mechanisms. In rat follicular cells, PRL-induced inhibition of progesterone release was accompanied by stimulation, and PRL-activated progesterone secretion in rat luteocytes by reduction of CAMP accumulation in the culture medium (Gitay-Goren et al, 1989a,b). In the granulosa cells, PRL prevented the steroidogenic effects of forskolin (a stimulator of cAMP production) (Krasnow et al, 1990), but not of 3-isobutyl-1-methylxanthine (a blocker of phosphodiesterase) (Gitay-Goren et al, 1989b). In other words PRL can act at the level of CAMP degradation rather than on cAMP synthesis. In our experiments, as with rat luteal cells, treatment with $P R L$ resulted in CAMP stimulation. The PRL effect had biphasic characteristics (fig 2). The mechanism and biological significance of this phenomenon remains unknown but it may confirm available data (Gitay-Goren et al, 1989ab; Krasnow et al, 1990) about cAMP involvement in the PRL action on the ovary. It is to be noted that the effects of PRL on other target tissues, for example on mammary gland, are probably not mediated by cAMP (Rillema et al, 1988).

The observed PRL-induced changes in ovarian CAMP release may be associated with the regulation of the secretion of steroids or of other substances, for example, oxytocin. In our experiments a significant PRL biphasic effect on oxytocin secretion was observed: low PRL doses inhibited, and high doses stimulated nonapeptide hormone output (fig 3). It is however important to note that the stimulatory effect of prolactin was observed only at supraphysiological doses $(\geq 1000 \mathrm{pmol} / \mathrm{ml}$ ). In the available literature we failed to find any reports concerning PRL influence on ovarian oxytocin. The cause and significance of such biphasic PRL effects on oxytocin release remain to be found. One can suggest that the stimulation of oxytocin release under the influence of high doses of PRL may reflect a luteotropic role of $P R L$; in ruminants the luteinization of granulosa cells is associated with the increase of oxytocin produciton (Wathes, 1989; Wathes et al, 1992). It cannot be excluded that the PRL-stimulated oxytocin release is due to the stimulation of CAMP production since the CAMP analogue dbcAMP or 3-isobutyl-1-methylxanthine can stimulate oxytocin release by bovine granulosa cells in culture (Wathes, 1989).

Thus the present observations, together with published reports, suggest the hypo- 
thesis that the first step in the action of PRL on ovarian cells includes the stimulation of cAMP formation and/or the inhibition of cAMP catabolism. The second step may be a CAMP-induced luteinization of the cell including specific changes in steroidogenesis (inhibition of estrogen and activation of progesterone secretion) and the stimulation of oxytocin release. On the other hand, a feedback effect of oxytocin (Nitray and Sirotkin, 1992) and steroid hormones (Sirotkin and Nitray, 1993) on cAMP release, as well as a reciprocal influence of steroids on oxytocin (Wathes, 1989; Sirotkin and Nitray, 1992) can also occur.

The fine interrelationships between ovarian cyclic nucleotides, steroid and nonapeptide hormones require further investigation, but these data suggest that PRL influences all these 3 classes of biologically active substances, playing an important role in the regulation of ovarian function.

\section{ACKNOWLEDGMENTS}

The authors thank AF Parlow (Harbor-UCLA Medical Center, Torrance, USA) and GV Marinchenko (Research Institute of Animal Breeding and Genetics, St Petersburg, Pushkin, Russia) for kindly providing USDA PRL B-1, A Lieskovska for technical assistance, and MR Luck (University of Nottingham, UK) for editing the manuscript.

\section{REFERENCES}

Adashi EY, Resnik CE (1987) Prolactin as an inhibitor of granulosa cells luteinuzation. Implications for hyperprolactinemia-associated luteal phase disfunction. Fertil Steril 48, 131139

Bevers MM, Dieleman SJ, Kruip TAM (1988) The role of prolactin during the oestrous cycle in cattle. Tijdschr Diergeneeskd 113, 1227-1236 (in Dutch)

Chedreese PJ, Rajkumar K, Ly H, Murphy BD (1988) Dose response of luteinized porcine granulosa cells in vitro to prolactin: dependency of pre-exposure to human chorionic gonadotropin. Can J Physiol Pharmacol 66, 1337-1340

Demura R, Ono M, Demura $H$, Shizame K, Ouchi $H$ (1982) Prolactin directly inhibits basal and gonadotropin-stimulated secretion of progesterone and $17 \beta$-estradiol in the human ovary. $J$ Clin Endocr Metab 54, 1246-1250

Dorrington JF, Gore-Langton RE (1982) Antigonadal action of prolactin: further studies on the mechanism of inhibition of follicle-stimulating hormone-induced aromatase activity in rat granulosa cells cultures. Endocrinology $110,1701-1707$

Dusza L (1989) Effect of prolactin on ovarian steroidogenesis. Acta Physiol Pol 44, 74-84

Dusza L, Tilton JE (1990) Role of prolactin in the regulation of ovarian function in pigs. $J$ Reprod Fertil Supp/ 40, 33-45

Einspanier R, Pitzel L, Wuttke W, Hagendarff G, Preuss KD, Kardalinou E, Scheit KH (1986) Demonstration of mRNA for oxytocin and prolactin in porcine granulosa and luteal cells. FEBS Lett 204, 37-40

Einspanier A, Jarry H, Pitzel L, Holtz W, Wuttke W (1991) Determination of secretion rates of estradiol, progesterone, oxytocin, and angiotensin II from tertiary follicles and freshly formed corpora lutea in free moving sows. Endocrinology 129, 3403-3409

Gitay-Goren H, Lindenbaum ES, Kraem L (1989a) Effect of prolactin on steroidogenesis and cAMP accumulation in rat luteal cell cultures. Molec Cell Endocrinol 65, 195-201

Gitay-Goren H, Lindenbaum ES, Kraem Z (1989b) Prolactin inhibits HCG-stimulated steroidogenesis and cyclic AMP accumulation possibility by increasing phosphodiesterase activity in rat granulosa cell cultures. Mol Cell Endocrinol 61, 69-76

Grazul A (1985) Release of progesterone by porcine luteal cells from different days of estrous cycle: effect of LH, PRL and PGF2. Endocrinol Exp 19, 117-128

Gregoraszczuk E (1985) Progesterone and androgen secretion by isolated cultured bovine corpus luteum cells: effect of LH, HCG, PRL, estradiol-17 $\beta$ and testosterone. Folia Histochem Cytobiol 23, 11-16

Grinwich DL, Mekibbin PE, Murphy BD (1983) Stimulation of progesterone secretion in the 
pregnant pig corpus luteum in vitro by prolactin and lipoproteins. In: Factors Regulating Ovarian Function (GS Greenwald, PF Terranova, eds) Raven Press, New York, 123-128

Guraya S (1985) Biology of Ovarian Follicles in Mammals. Springer-Verlag, Berlin, New York, $320 \mathrm{p}$

Hansel W, Dowd JP (1986) New concepts of the control of corpus luteum function. J Reprod Fertil 78, 755-768

Hunter MG (1989) Prolactin stimulates steroidogenesis by human luteal tissue in vitro. $J$ Endocrinol 103, 107-110

Kalison B, Warshaw ML, Gibari G (1985) Contrasting effects of prolactin on luteal and follicular steroidogenesis. J Endocrinol 104, 241-250

Krasnow JS, Hickey GL, Richards JS (1990) Regulation of aromatase messenger RNA and estradiol biosynthesis in rat ovarian granulosa and luteal cells by prolactin. Mol Endocrinol 4, 13-21

Ledwitz-Rigby $F$ (1987) Local regulation of granulosa cells maturation. J Steroid Biochem 27, 385-391

Magoffin DA, Erickson GF (1982) Prolactin inhibition of luteinizing hormone-stimulated androgen synthesis in ovarian interstitial cells cultured in defined medium: mechanism of action. Endocrinology 111, 2001-2007

McNeilly AS, Glasier A, Jonassen J, Howie PW (1982) Evidence for direct inhibition of ovarian function by prolactin. $J$ Reprod Fertil 65 , 559-569

McNeilly AS (1984) Prolactin and ovarian function. In: Neuroendocrine Perspectives (EE Muller, RM Mac Lead, eds). Elsevier Science Publishers, Amsterdam, 279-315

Menon M, Peegel H, Menon KMJ (1985) Lipoprotein augmentation of human chorionic gonadotropin and prolactin stimulated progesterone synthesis by rat luteal cells. J Steroid Biochem 22, 79-89

Murphy BD, Rajkumar K (1985) Prolactin as a luteotropin. Can J Physiol Pharmacol 63, 257269

Nitray J, Sirotkin AV (1992) Reciprocal control of oxytocin and CAMP production by porcine granulosa cells in vitro. Ann Endocrinol 53, 28-31

Rajkumar K, Klingshorn PJ, Chedrese PJ, Murphy $\mathrm{BD}$ (1988) Prolactin, $\mathrm{LH}$ and estradiol-17 $\beta$ in utilization of lipoprotein substrate by porcine granulosa cells in vitro. Can J Physiol Pharmacol 66, 561-566

Richards JS, Hedin L (1988) Molecular aspects of hormone action in ovarian follicular development, ovulation, and luteinization. Annual Rev Physiol 50, 441-463

Rillema JA, Etindi RN, Ofenstein JP, Waters SB (1988) Mechanism of prolactin action. In: The Physiology of Reproduction (E Knobil, J Neill, eds) Raven Press, New York, 2217-2234

Roy SK, Wang SC, Greenwald GS (1987) Radioreceptor and autoradiographic analysis of $\mathrm{FSH}, \mathrm{HCG}$ and prolactin binding sites in primary to antral hamster follicles during the preovulatory period. J Reprod Fertil 79, 307-313

Sato EA, Tureck RW, Strauss JF (1985) Effect of prolactin on progestin secretion by human granulosa cells in culture. Biol Reprod 32, 541-545

Sirotkin AV, Nitray J (1992) Interrelationships between nonapeptide and steroid hormones secretion by porcine granulosa cells in vitro. $J$ Steroid Biochem Molec Biol 43, 529-534

Sirotkin AV, Nitray J (1993) Steroid hormones regulate CAMP and CGMP production by porcine granulosa cells in vitro. J Steroid Biochem Molec Biol (in press)

Tsafriri A (1988) Local nonsteroidal regulators of ovarian function. In: Physiology of Reproduction (E Knobil, J Neill, eds). Raven Press, New York, 527-565

Wang $\mathrm{CH}$, Chan V (1982) Prolactin suppress estrogen and stimulates progesterone production by granulosa cells of preovulatory rat ovarian follicles. In: Follicular Maturation and Ovulation (R Rolland, V Van Hall, SG Hillier, KP McNatty, eds). Excerpta Medica, Amsterdam, 91-96

Wathes DC (1989) Oxytocin and vasopressin in the gonads. Oxford Rev Reprod Biol 11, 226283

Wathes DC, Kendall PAD, Perks C, Brown D (1992) Effects of stage of the cycle and estradiol-17 $\beta$ on oxytocin synthesis by ovine granulosa and luteal cells. Endocrinology 130 , 1009-1016

Zadworny D, Shimada K, Ishida H, Sato K (1989) Gonadotropin-stimulated estradiol production in small ovarian follicles in the hen is suppressed by physiological concentrations of prolactin in vitro. Gen Comp Endocrinol 74, 468-473 